African J. Biol. Sci., 17 (1): 221-231 (2021)

ISSN 1687-4870

www.ajbs.journals.ekb.eg

e- ISSN 2314-5501 (online)

E.mail: aasdjournal@yahoo.com

\title{
Evaluation of the antimicrobial activity of purified Spodoptera littoralis hemolymph against some pathogenic bacteria
}

\author{
Hanan S. Amer', Doaa Soliman², Wael S. Abdel-Mageed ${ }^{3}$, Shimaa A.Mo'men², Tamer \\ Roshdy ${ }^{3}$ and Nadia M. Lotfy ${ }^{2}$ \\ 1- Ain Shams Univ. Specialized Hospital, Cairo, Egypt \\ 2- Entomology Department, Faculty of Science, Ain Shams Univ.
}

3- Molecular Biology Department, Genetic Engineering and Biotechnology Research Institute, Sadat Univ., Menoufia, Egypt

4- Corresponding Author E-mail: Hantoosh27@yahoo.com

Received: May 12, 2021; Accepted: September 2, 2021; Available online: September 9, 2021

\begin{abstract}
The effect of the Phenoloxidase (PO) on bacterial culture and its bioactivity is a big concerns nowadays because of the movement towards natural antibiotics instead of the chemical ones. In this study the prophenoloxidase (PPO) was activated to PO in Spodoptera littoralis by injection of series concentrations from Bacillus thuringiensis kurstaki (BT) (3200 IU/mg, AGERIN- wettable powder) $2 \times 10^{10}, 2 \times 10^{20}, 2 \times 10^{30}, 2 \times 10^{40}, 2 \times 10^{50}$ and $2 \times 10^{60}$ cells $/ \mathrm{ml} .10$ $\mu 1$ of each bacterial concentration was injected into groups from 10 larvae each, with a total 656 larvae. 519 of the injected larvae were live and 137 died. It was found that the stock concentration $2 \times 10^{60}$ was the LC20 concentration. After the injection and inoculation for $24 \mathrm{hrs}$, the larvae had been disinfected and the haemolymph separated. Purification for PO from the haemolymph had been done using HiTrapTM CM FF 1ml column. After assuring the presence of PO by SDS gel, it was cultured against six types of bacteria, two gram +ve (Staph. aureus, Enterococci) and four gram -ve (E. coli, Pseudomonas, Acinetobacter and Klebsiella). It was effective against the gram positive bacteria and against $E$. coli only from the gram negative bacteria. Therefore, it could be concluded that the PO has bioactivity toward the gram positive bacteria more than the gram negative ones.
\end{abstract}

Keywords: Spodoptera littoralis, haemolymph, Phenoloxidase, Bacillus thuringiensis, gram +ve bacteria, gram -ve bacteria, bioactivity.

INTRODUCTION

Insects combat disease by mounting capable immune reactions that are interceded by hemocytes, the fat body, the midgut, the salivary organs and other tissues (Hillyer, 2016). They depend exclusively on a well-developed natural resistant framework to protect themselves against microbial diseases (Franssens, 2006). Insects need a procured immune system and depend exclusively on the intrinsic safe framework to combat microbial disease. Upon microbial infection, a course of action of small peptides and proteins are conveyed and released into the haemolymph (Prasad et. al. 2020). In insects, antimicrobial peptides/ polypeptides are synthesized mainly in a fat body (functional analogue of mammalian liver) and are released into haemolymph where they play a crucial role in innate immune systems and host defense mechanisms, and having a broad spectrum of activity against both Gram +ve and Gram 


\section{Hanan S. Amer et al.}

-ve bacteria and against fungi (Hoffmann, 1995; Hoffmann et al., 1996; Januszanis et al., 2012). The era of Antimicrobial peptides (AMPs) is exceedingly inducible taking after a microbial contamination, the levels of AMPs modify from by and the large intangible in uninfected insects to micromolar concentrations in haemolymph of damaged ones. Expression of these AMPs comes essentially from fat body in show disdain toward of the reality that hemocytes as well contribute to their generation (Rosales, 2017). The components of AMP activity are thought of as an interaction with the bacterial cell membrane (Kumar et al., 2018). Mode of activity might relate to targeting metabolic forms within the bacteria including cell divider blend, nucleic corrosive or protein blend, which are crucial to the organism (Ebbensgaard et. al., 2015).

Antimicrobial resistance is rising to hazardously tall levels in all parts of the world. Unused resistance components are developing and spreading universally, threatening our capacity to treat common irresistible illnesses. A developing list of diseases such as pneumonia, tuberculosis, blood harming, gonorrhea, and foodborne infections are getting to be harder and now and then incomprehensible, to treat as antimicrobial gotten to be less successful (WHO, 2018). AMPs are conceivable candidates for the plan of unused antimicrobial agents since of their common antimicrobial properties and a low penchant for improvement of resistance by microorganisms. This composition surveys the current information of the fundamental science of AMPs and their applications in non-ruminant nourishment. Antimicrobial peptides not as it were have broad-spectrum movement against microscopic organisms, parasites, and infections but moreover have the capacity to bypass the common resistance instruments that are putting standard antimicrobials in risk (Wang et al., 2016). The present study aimed at evaluating the resistant of different gram negative and gram positive bacteria against one of the AMP component, Phenoloxidase, in order to examine the antimicrobial activity as a primary step for new antibiotic era.

\section{MATERIALS AND METHODS \\ Insect rearing and pathology assays}

The adult leaf-worm Spodoptera littoralis was obtained from the Central Agribusiness Pesticides Investiagate Office (CAPL), Dokki, Giza, Egypt. Larvae were reared in insectarium on an artificial diet (Poitout et al., 1970) at $23 \pm 1{ }^{\circ} \mathrm{C}$, with a photoperiod of $16 \mathrm{hrs}$ light: $8 \mathrm{hrs}$ darkness and a relative humidity of $40 \pm \%$.

\section{Bacterial suspension}

Pathogenicity experiments were performed by injecting a suspension of Bacillus thuringiensis kurstaki (BT) bacteria in the exponential growth phase $\left(2 \times 10^{10}\right.$ cells/ml of LB broth) into fifth instar larvae (Bisch et al., 2015). Six independent pathogenicity assays were performed for Bacillus thuringiensis in the S. littoralis pathoassay to obtain the sublethal dose. 10 larvae were used for each concentration.

\section{Haemolymph Collection:}

The living infused and uninjected (control group) cotton leaf worms were expelled from the raising cages, and submerged in hot water shower at $60^{\circ} \mathrm{C}$ for $2-5 \mathrm{~min}$, then permitted to dry on paper towel. The living larvae were severed at the rear coxa with fine scissors, the haemolymph was gotten with a fine-tipped calibrated glass capillary, which was kept at $-20^{\circ} \mathrm{C}$ for further use in detecting the antimicrobial peptides (Miranpuri and Khachatourians, 1993)

Antimicrobial peptide purification:

The refinement of the enzyme had been done utilizing HiTrap TM CM FF $1 \mathrm{ml}$ 


\section{Evaluation of the antimicrobial activity of purified Spodoptera littoralis hemolymph against some pathogenic bacteria}

column bought from GE Healthcare. CM Sephrose Fast Flow, is based on a vigorous, $6 \%$ highly cross-linked beaded agarose matrix with excellent stream propert ies and tall stacking capacities. Two groups of haemolymph (injected and control) had been centrifuged at 12,000 for 10 mins, the additives were washed out by filling the syringe with $5 \mathrm{ml}$ buffer (bis-tris $\mathrm{PH}$ 5). At that point washing with $5 \mathrm{ml}$ of elution buffer (buffer with $1 \mathrm{M} \mathrm{NaCl}$ ) (JaeJoon and Woo-Yeon, 2013). Equilibrate with $5 \mathrm{ml}$ start buffer. Apply the supernatant of the haemolymph to the column by the syringe, washed with start buffer with the same amount of connected haemolymph eluted with $5 \mathrm{ml}$ solution buffer.

Haemolymph proteins were analyzed by SDS-polyacrylamide gel (Laemmli, 1970) method. Concentration of the protein in the injected and uninjected sample had been tested by NANODROP 2000c spectrophotometer from Thermo SCIENTIFIC.

Preparation of microbial cells A standardize bacterial suspension $(0.5$ McFarland) was obtained from microbiology unit, central lab, Ain Shams Specialized Hospital and prepared and measured by densitometer "BIOME'RIEUX, DensiCHEK plus". Two gram positive bacterial suspensions had been prepared; Staphylococcus aureus, and Entero cocci, and four gram negative bacterial suspensions had been prepared; Escherichia coli, Pseudomonas aeruginosa, Acinetobacter baumannii, and Klebsiella pneumonia. All bacterial cultures were grown overnight at $37^{\circ} \mathrm{C}$ in rich nutrient media until reaching a stationary phase.

Antibacterial activity of collected haemolymph: Microbial growth inhibition was tested using agar well diffusion method (Magaldi et al., 2004; Valgas et al., 2007). In this procedure, agar plates were inoculated with a standardized inoculum of the test microorganism. Then, adding $10 \mu /$ drop from the purified haemolymph on the agar surface. The Petri dishes are incubated under suitable conditions. Generally, antimicrobial agent diffuses into the agar and inhibits germination and growth of the tested microorganism and then the diameters of inhibition growth zones were measured.

\section{RESULTS \\ Haemolymph purification:}

Concentration of the protein in the injected and uninjected samples had been tested by "NANODROP 2000c spectrophotometer from Thermo SCIENTIFIC", $2 \mu \mathrm{g} / \mathrm{ml}$ from the sample, the concentration of the injected sample was $106 \mu \mathrm{g} / \mathrm{ml}$ and the protein concentration in uninjected sample was $190 \mu \mathrm{g} / \mathrm{ml}$.

\section{SDS-PAGE Profiles:}

Concerning the total cellular proteins of hemolymphs isolates, 14 bands of hemolymphs were fractionated in denaturing gel electrophoresis (SDSPAGE) MW 200, $150,120,100,85,70,60,50,40,30,25,20$, 15 and $10 \mathrm{kDa}$ (Fig. 1). Comparison of protein patterns from marker and purified hemolymph isolates indicated that there was 1 common band MW 65 kDa (Fig. 1).

\section{Bacterial susceptibility against AMP'S:}

The antibacterial activity of hemolymph of $S$. litorallis against different strains of Gram-positive and Gram-negative bacteria is indicated in Table (1). The Collected hemolymph was injected immediately after isolated. The inhibition zone with the gram positive bacteria Enterococci was (1, 1.1 and $0.9 \mathrm{~cm})$ and with Staph aureus was $(2,2.2$ and $1.8 \mathrm{~cm})$ (Fig. 2). In case of gram negative the inhibition zone with E.coli was (1.5, 1.7 and $1.4 \mathrm{~cm})$. For other gram negative no inhibition zone was found (Fig. 3). In case of hemolymph tested after 60 minutes and 
Hanan S. Amer et al.

uninjected hemolymph there was no inhibition zone with gram positive or gram negative bacteria and there were no

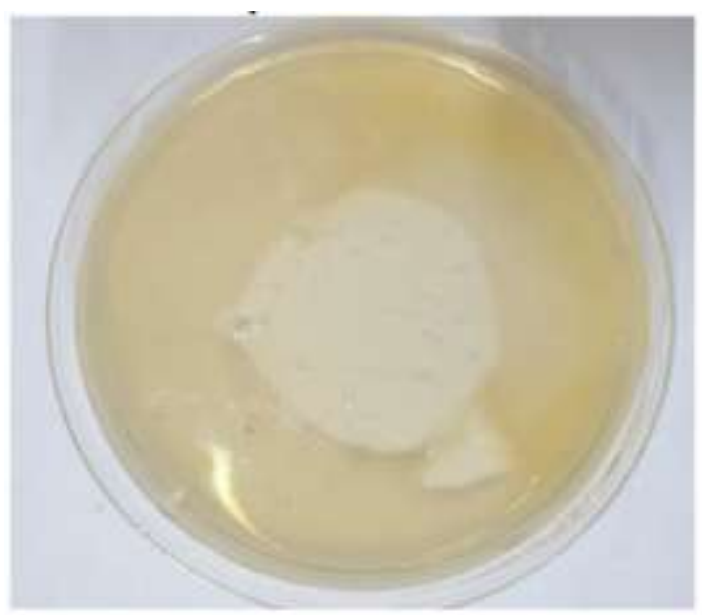

Staph aureus inhibition zone statistically significant difference between Gram positive and Gram negative Bacteria (Table 1).

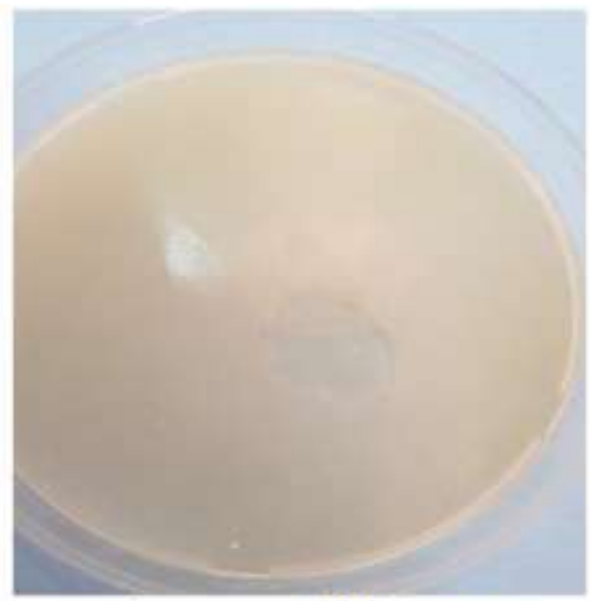

Enterococcoi inhibition zone

Fig. 1. Protein bands of marker and purified haemolymph of Spodoptera litorallis adults determined from SDS- PAGE.

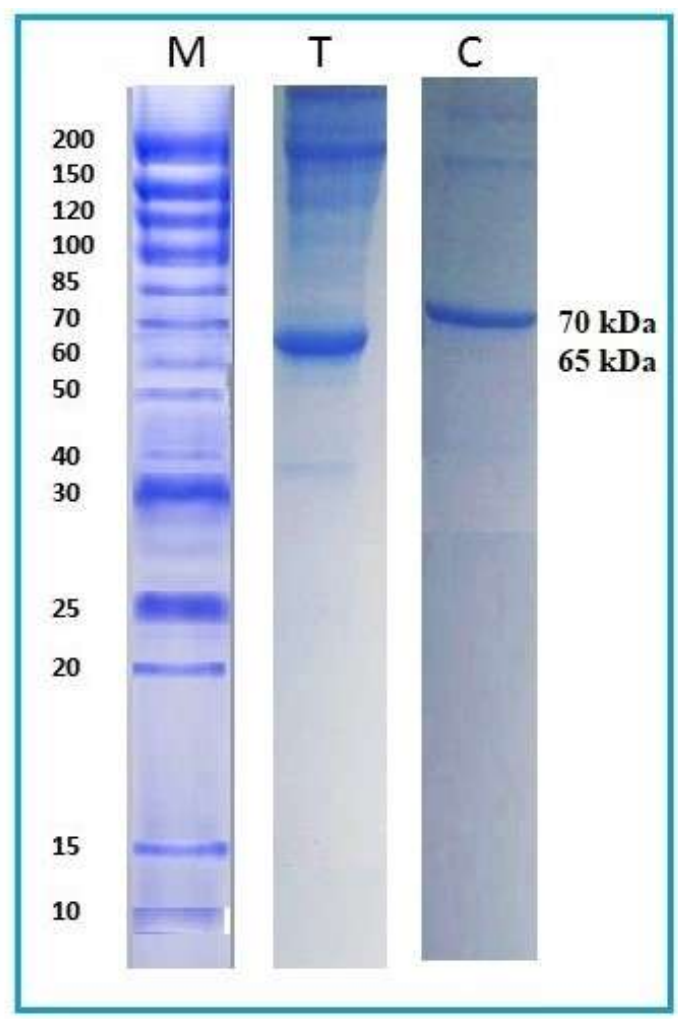

Fig. 2. inhibition zone with gram positive bacteria 
Evaluation of the antimicrobial activity of purified Spodoptera littoralis hemolymph against some pathogenic bacteria
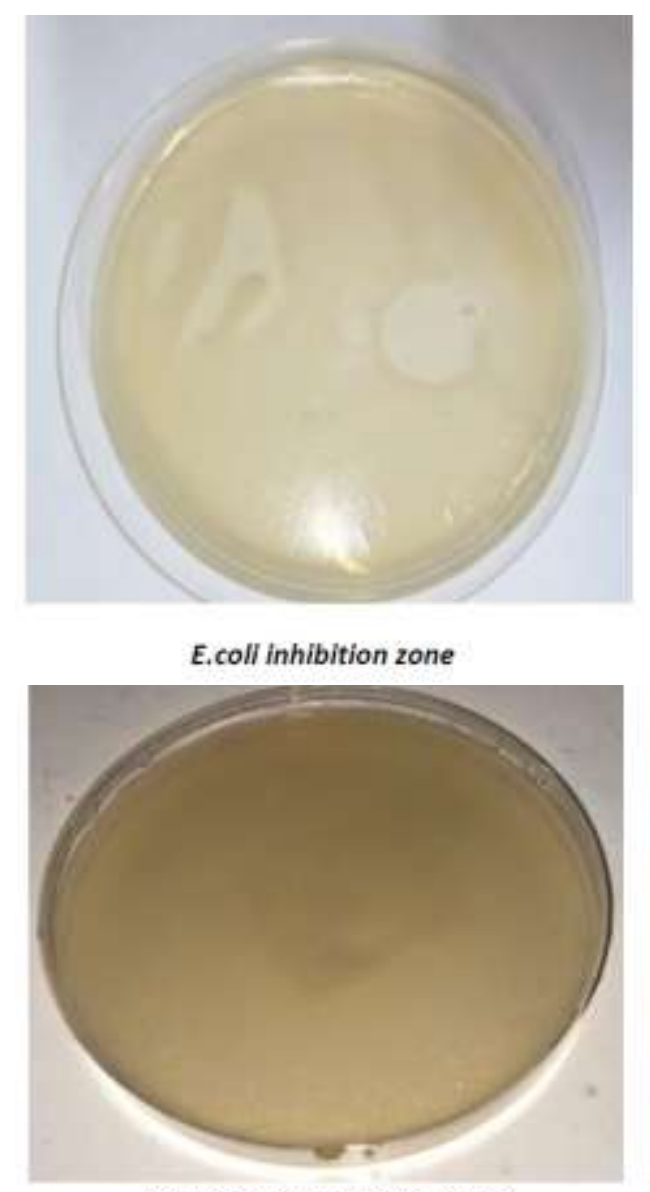

Acinetobacter inhibition zone

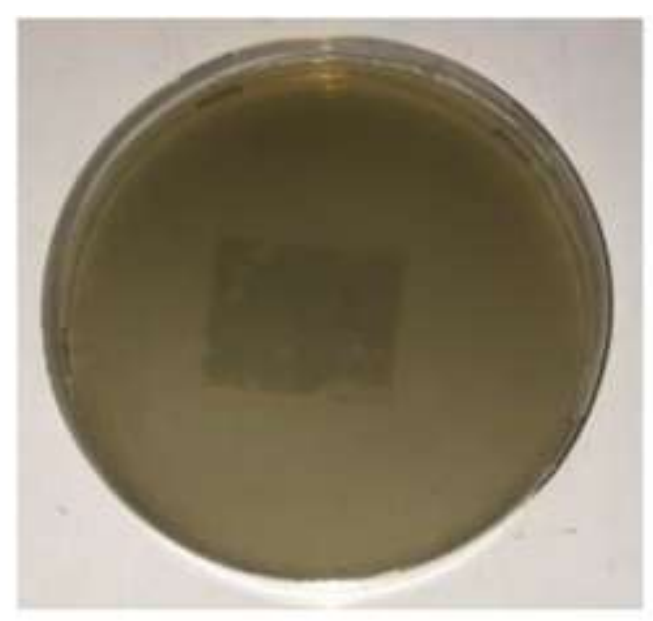

Pseudomonas inhibition zone

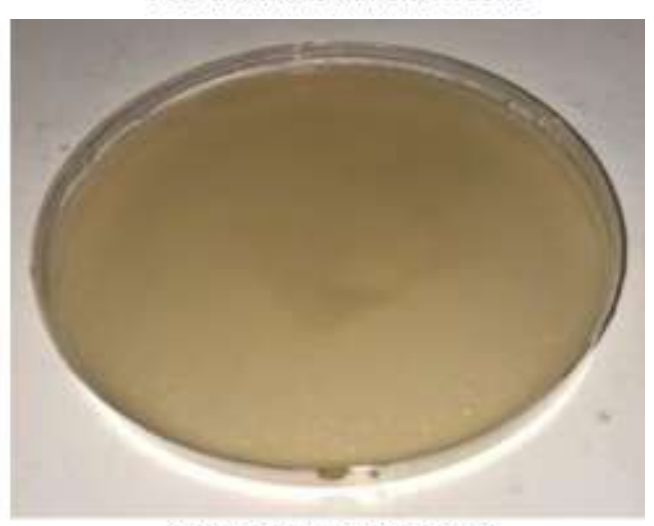

Klebsiella inhibition zone

Fig (3): Inhibition zone with gram negative bacteria

Table (1): Antibacterial activity of the haemolymph of $S$. litorallisagainst different strains of Gram-positive, Gram-negative bacteria

\begin{tabular}{|l|l|l|l|l|}
\hline \multirow{2}{*}{ Collected hemolymph } & \multicolumn{2}{|l|}{ Inhibition zone $(\mathbf{c m})($ mean \pm SE) } & \multirow{2}{*}{ t-test } & \multirow{2}{*}{ p-value } \\
\cline { 2 - 5 } & Gram +ve Bacteria & Gram -ve Bacteria & & \\
\hline Immediately isolated & $1.53 \pm 0.09$ & $1.50 \pm 0.07$ & 0.374 & 0.714 \\
\hline After 60 min & $0 \pm 0$ & $0 \pm 0$ & --- & --- \\
\hline Uninjected sample & $0 \pm 0$ & $0 \pm 0$ & --- & --- \\
\hline
\end{tabular}

Using: Independent Sample t-test; $p$-value $>0.05 \mathrm{NS}$

\section{DISCUSSION}

Multidrug resistant bacteria are a global threat to the human health and abusing of antibiotics is the main cause of this problem. Research for new natural antibiotic is the new era those days. Insects resist the bacterial infection by mounting powerful immune responses that are intervened by hemocytes, the fat body, the midgut, the salivary glands and other tissues (Hillyer, 2016). Phenoloxidase is the authoritative of invaders' PAMPs on 


\section{Hanan S. Amer et al.}

PRPs actuates the mix of proteins or starts the

antimicrobial proteolytic incitation of phenoloxidase cascade (Yu XQ et al., 2002; Marmaras and Lampropoulou, 2009; Tsakas and Marmaras, 2010). Spodoptera littoralis was the insect chosen in this study, since it had demonstrated a great success in this kind of immunelogical thinks (Paterson et al., 1987; Seufi et al., 2011; Basiouny et al., 2016). This comes from the reality that they can be easily reared with cheap media and materials, can be kept up in huge numbers, easily identified, have a quick lifecycle and they have huge blood volume. According to Gholami et al., (2013) , the Phenoloxidase (PO) microbial activity may decrease by $50 \%$ after mins. This is why three samples had been tested and it has been supported by this study as the sensitivity showed in the immediate phenoloxidase had been disappeared after $1 \mathrm{hr}$. The antimicrobial impact of responsive intermediates deliverd in the phenol oxidase-catalyzed responses. After being treated with Manduca sexta phenoloxidase and dopamine, tiny examination appeared melanin testim ony on cell surface, accumulation of bacteria, and misfortune of cell versatility. Viability tests uncovered the major diminishes within the bacterial colony counts and since the diminish remained noteworthy after scattering of the cell clumps, the receptive compounds were derived to have amassed and killed $E$. coli and $B$. subtilis cells. Beneath the exploratory conditions, $60-94 \%$ of the Gram-negative microscopic organisms (E.coli, Klebsiella pneumoniae, Pseudomonas aeruginosa, and Salmonella typhimurium) and 52-99\% of the Grampositive microscopic organisms (Bacillus cereus, B. subtilis, Micrococcus luteus, and Staphylococcus aureus) were killed. wWithin the nearness of phenol oxidase (Zhao et al., 2007). While in this study the effect of PO on gram positive bacteria (Staph. aureus and Enterococci) was greater than the effect on gram negative bacteria, as long as on the gram negative it affect only the growth of the E.coli and this may be due to the weakness of the E. coli as a strain, while on the remaining strong pathogenic gram negative tested strain (Pseudomonas, Acinetobacter and Klebsiella) it showed no effect on their growth. The results mentioned in this study indicated that the PO has an antibiotic activity toward the bacteria, specially the gram positive and may have effect on the weak gram negative bacteria.

Referring to Gonzalez-Santoyo and Cordoba-Aguilar (2011) PO are expressed as dormant zymogens (proPOs) in all insects and are changed over to active $\mathrm{PO}$ when required. ProPOs are polypeptides with a total weight of 5060 and $70-80 \quad \mathrm{kDa}$ in their active and inactive frame.

In this study, PO was purified with different purification protocols. The molecular weight of PO was estimated on SDSPAGE with a single band of approximately $70 \mathrm{kDa}$. The molecular mass of PO from other markers has been reported as follows: protein markers were separated into 14 bands with molecular weights (MW) 200, 150, 120, 100, 85, 70, 60, 50, 40, 30, 25, 20, 15 and $10 \mathrm{kDa}$. These marker proteins used as a reference for the apparent separated protein bands. Schnepf et al. (1998) and De Maagd et al. (2001) reported that Delta-endotoxins from the sporeforming bacterium, Bacillus thuringiensis, are toxic to a variety of insect species with a very high specificity. Susceptibility of pests to these toxins is influenced by the accomplishment of many steps such as crystal solubilization, protoxin activation by midgut proteases (Lightwood et al., 2000; Rausell et al., 2004), and binding of the toxin to the receptors located on the brush 


\section{Evaluation of the antimicrobial activity of purified Spodoptera littoralis hemolymph against some pathogenic bacteria}

border membrane vesicles (BBMV) (Schnepf et al., 1998). An alteration in one of these steps may be a cause of larvae sensitivity modification or resistance emergence (Ferré and Van Rie, 2002). Abdelkefi et al. (2011) reported that $B$. thuringiensis toxin has a higher LC50 when tested against $S$. littoralis larvae. The authors demonstrated that B. thuringiensis was active against first instar larvae of the polyphagous S. littoralis with an LC50 of about $305 \mathrm{ng} / \mathrm{cm}^{2}$.

In the present study the susceptibility tests of $S$. litorallis adult indicated that the mortality percentages were recorded after 24 $\mathrm{hr}$ for B. thuringiensis post-injection. The estimated LC50 value, at $95 \%$ probability, was $2 \times 10^{7}$ cells $/ \mathrm{ml}$. The estimated LC20 was $2 \times 10^{6}$ cells $/ \mathrm{ml}$. This concentration was found to stimulate the immune response of larvae and at the same time did not cause high mortality rate. Therefore, this concentration $2 \times 10^{6}$ cells $/ \mathrm{ml}$ was used as sublethal concentration to investigate the subsequent experiments.

The Hemolymph PO has been implicated in resistance to a range of pathogens, including nucleopolyhedro viruses (NPVs), fungi, nematodes and parasitoids (Rowley et al, 1990; Ourth and Renis, 1993; Hagen et al., 1994; Hung and Boucias, 1996; Washburn et al., 1996; Bidochka and Hajek, 1998; Reeson et al., 1998). However, PO in other parts of the body may also play an important role in immunity. NPVs enter the body via the midgut and proceed by infecting the associated tracheal cells (Washburn et al., 1996). The authors showed that in refractory Helicoverpa zea, these infected cells were encapsulated and melanized, halting the spread of the virus. This suggests a possible role for midgut $\mathrm{PO}$ in viral resistance. In Anopheles gambiae, Plasmodium cynomolgi ookinetes are encapsulated between the midgut epithelial cells and the midgut basal lamina. It has been shown that refractory individuals have higher midgut PO levels than susceptibles after an infective blood meal. This suggests that their refractoriness may, in part, be due to phenoloxidase activity (Paskewitz et al., 1989). PO has also been used as an indicator of immune function, for example, Reeson et al. (1998) showed that larvae of the African armyworm, Spodoptera exempta, that had been reared at high densities had significantly higher haemolymph PO levels and higher NPV resistance than those reared solitarily. However, a direct link between PO activity and intra-specific variation in parasite resistance has yet to be conclusively demonstrated and it is important to examine the association between PO and pathogen resistance, and to determine any associated costs of pathogen resistance (Wilson et al., 2001).

Hassan et al. (2012) reported that the present findings showed that, larval hemolymph of untreated and treated samples of $S$. littoralis had 18 bands of proteins. The protein patterns had $\mathrm{Rf}$ ranged from 0.02 to 0.74 . Also, there were differences in the protein patterns between treated and untreated larvae. The treatment with novaluron and pyrialyl caused disappearance of normal bands and /or appearance of abnormal bands as compared to the control samples.

Ashida and Brey (1997) reported that PO are expressed as inactive zymogens (proPOs) in all insects and are converted to active PO when required. ProPOs are polypeptides that contain two copper atoms per protein molecule, with a total weight of 50-60 and 70-80 kDa in their active and inactive forms, respectively.

In this study the larvae of $S$. littoralis were more susceptible to gram positive bacterial than gram negative bacterial. This 


\section{Hanan S. Amer et al.}

difference in pathogenicity came from the presence of an outer membrane in the cell wall of $\mathrm{G}$-ve bacteria, made up of LPS and acted as an endotoxin, which was absent in gram positive bacterial (Sewify et. al. 2017).

The normal insects exhibited a very weak antibacterial activity towards virulent bacteria without receiving any antigenic challenge, because of naturally occurring antimicrobial substances found in the food. Indeed, a weak antibacterial response to water challenge (control) was observed and may be due to either a lower sensitivity or a higher induction-specificity of the larval immune system. The bacterial virulence factor (SEA) induced the strongest antimicrobial activity in larval hemolymph against all the studied bacterial species.

Hemolymph of bacteria-injected $S$. littoralis larvae recorded drastic changes in both the total protein content and the protein banding patterns following injections.

The PO antimicrobial activity decreased significantly after $1 \mathrm{~h}$ postinjection. This can be attributed to the intensive consumption of plasma proteins during multiplication and growth of bacteria. Also, some hemolymph sticky and soluble proteins may be involved in the attachment of the injected pathogens to the hemocytes or some native proteins might be converted into glycoproteins or lipoproteins after injection (Gholami et. al 2013).

Demir et al. (2002) reported that Klebsiella spp. and Enterobacter spp. are closely associated with many insect species and species belonging to these genera and they are not generally insect pathogens. They probably play roles in the digesting processes in the insect gut and in the physiological developments of $S$. littoralis larvae (Ademolu and Idowu, 2011). Klebsiella species (SL2 and SL5) and 2 Enterobacter (SL3 and SL4) strains were isolated from $S$. littoralis. The Enterobacter isolates did not show good activity against $S$. littoralis, while the Klebsiella species caused significant mortalities in $S$. littoralis larvae. (Demir et al., 2002; Ademolu and Idowu, 2011).

Staphylococcus species have been isolated from different insect species (İnce $e t$ al., 2008), although Bucher (1981) indicated that Staphylococcus species are rarely associated with insects. In the current study Staphylococcus sp. was isolated from SL9 S. littoralis larvae, but this isolate did not show significant mortality in the pest. Ravensberg (2011) indicated that all larval stages of $S$. littoralis were susceptible to the isolate Bacillus thuringiensis subsp. Kurstaki $(\mathrm{MnD})$ at the same rate, except for the second-instar larvae. The second-instar larvae were also infected with $\mathrm{MnD}$, but they were found to be more resistant than the other development stages. In most cases, all larval stages of insect pests are susceptible to pathogens; therefore, often the larval stage is the preferred stage in field studies (Ravensberg, 2011).

\section{REFERENCES}

Basiouny, A.; Ghoneim, K.; Tanani, M.; Hamadah, K.H. and Waheeb, H. (2016). Disturbed protein content in Egyptian cotton leafworm Spodoptera littoralis (Boisd.) (Lepidoptera: Noctuidae) by some novel chitin synthesis inhibitors. Int. J. Adv. Res. Biolog. Sci., 3(3):, 1-12.

Ben, M.S. and Schmid-Hempel, P. (2006). Insect immunity shows specificity in protection upon secondary pathogen exposure. Current biology : $C B$ : 16(12):1206-1210.

Broderick, N.A.; Robinson, C.J.; McMahon, M.D. (2009). Contributions of gut bacteria to Bacillus thuringiensisinduced mortality vary across a range of Lepidoptera . BMC Biol., 7: 11 


\section{Evaluation of the antimicrobial activity of purified Spodoptera littoralis hemolymph against some pathogenic bacteria}

Carlos, R. (2017). Cellular and molecular mechanisms of insect immunity. Insect Physiology and Ecology, published by INTECH open science, 179-212. DOI: 10.5772/67107.

Campbell,JJR. and Konowalchuk, J. (1948). Counts of Bacteria in Raws Milk. Canad. J. Res., 26e(6): 295-298

De Maagd, R.; Bravo, A. and Crickmore, N. (2001). How Bacillus thuringiensis has evolved specific toxins to colonize the insect world. Trends in genetics (TIG), 17: 193-9. DOI:10.1016/S0168-9525(01)02237-5.

Dillon, R.J. and Dillon, V.M. (2004). The gut bacteria of insects, Nonpathogenic Interactions. Ann. Rev. Entomol., 49:71-92.

Ebbensgaard, A.; Mordhorst, H.; Overgaard, M.T.; Nielsen, C.G.; Aarestrup, F.M. and Hansen, E.B. (2015). Comparative evaluation of the antimicrobial activity of different antimicrobial peptides against a range of pathogenic bacteria. PLoS ONE, $10(12)$ : e0144611. doi:10.1371/journal.pone.0144611

Franssens, V. (2006). Study of two types of immune responses in insects: nodulation in the flesh fly, Neobellieria bullata, and prophenoloxidase activation in the desert locust, Schistocerca gregaria. MEI press.

González-Santoyo, I. and Córdoba-Aguilar, A.(2011). Phenoloxidase: a key component of the insect immune system. J. Entomol Experimentalis et Applicata. DOI: 10.1111/j.15707458.2011.01187.x

Gholami, T.; Ghadamyari, M.; Oliaee, A. O. and Ajamhasani, M. (2013). Effects of inhibitors on haemolymph phenoloxidase from rosaceous branch borer, Ospheranteria coerulescens (Coleoptera:

Cerambycidae). J. Plant Prot.

Res., 53(4), 324-332. At

https://doi.org/10.2478/jppr-20130049

Heimpel, A.M. and Angus, T.A. (1960). Bacterial insecticides. Bacteriol. Rev., 24: 266-288.

Hillyer, J.F. (2016). Insect immunology and hematopoiesis. Dev. Comp. Immunol., (58): 102-118.

Kamal, M. (1951). The biological control of the cotton leafworm Prodenia litura F. in Egypt. Bull. Soc. Ent. Egypt, 35: 221-270.

Kim, J.J. and Kim, W.Y. (2013). Purification and characterization of polyphenol oxidase from fresh ginseng. J. Ginseng Res., 37(1): 117-123. https://doi.org/10.5142/jgr.2013.37.1 17

Kumar, P.; Kizhakkedathu, J.N. and Straus S.K. (2018). Antimicrobial peptides: diversity, mechanism of action and strategies to improve the activity and biocompatibility in vivo. Biomolecules, 8(1): 4.

Marmaras VJ, Lampropoulou M. Regulators and signalling in insect haemocyte immunity. Cell Signal. 21: 186-95, 2009.

Miranpuri, G.S. and Khachatourians, G.G. (1993). Role of bioinsectictdes in integrated pest management (IPM) and insect resistant management (IRM) practices. J. Insect Sci., (6): 161-172.

Moore, I. and Navon, A. (1973). Studies of the susceptibility of the cotton leafworm, Spodoptera littoralis (boisduval), to various strains of Bacillus thuringiensis Phytoparasitica, 1: 23-32. 
Hanan S. Amer et al.

Laemmli, U.K. (1970). Cleavage of structural proteins during the assembly of the head of bacteriophage T4. Nature, 227:680685.

Paterson, R.R.M.; Simmonds, M.S.J. and Blaney, W.M. (1987). Mycopesticidal effects of characterized extracts of Penicillium isolates and purified secondary metabolites (including mycotoxins) on Drosophila melanogaster and Spodoptora littoralis. J. Invert. Pathol., 50(2): 124-133.

Prasad, S.V.; Fiedoruk, K.; Daniluk, K.; Piktel, E. and Bucki, R. (2020). Expression and Function of Host Defense Peptides at Inflammation Sites. Int. J. Mol. Sci., 21(1): 104. doi.org/10.3390/ijms21010104

Schnepf, E.; Crickmore, N.; Van Rie, J.; Lereclus, D.; Baum, J.; Feitelson, J. and Zeigler, D.R. (1998). Bacillus thuringiensis and its pesticidal crystal proteins. Microbiol. Mol. Biol. Reviews, 62(3): 775-806.

DOI: 10.1128/MMBR.62.3.775806.1998

Seufi, A.M.; Hafez, E.E. and Galal, F.H. (2011). Identification, phylogenetic analysis and expression profile of an anionic insect defensin gene, with antibacterial activity, from bacterialchallenged cotton leaf-worm, Spodoptera littoralis. BMC Molecular Biology, 12(1): 47.
Sewify GH., Hamada HM., Alhadrami HA.(2017). In Vitro Evaluation of Antimicrobial Activity of Alimentary Canal Extracts from the Red Palm Weevil, Rhynchophorus ferrugineus Olivier Larvae. BioMed Res. Int. Vol 2017, Article ID:8564601.

doi.org/10.1155/2017/8564601

Tsakas, S. and Marmaras, V. (2010). Insect immunity and its signaling: an overview. Invert. Surv. J. (ISJ), 7:228-238.

Wang, S.; Zeng, X.; Yang, Q. and Qiao, S. (2016). Antimicrobial Peptides as Potential Alternatives to Antibiotics in Food Animal Industry. Int. J. Mol. Sci., 17(5): 603.

Wang, Q.; Ren, M.; Liu, X.; Xia, H. and Chen, K. (2019). Peptidoglycan recognition proteins in insect immunity. J. Mol. Immunol., 106:69-76.

WHO (2018). Antibiotic Resistance -Fact Sheets. At https://www.who.int/newsroom/fact-sheets/detail/antibioticresistance

Yu, X.Q.; Zhu, Y.F.; Ma, C.; Fabrick, J.A.; Kanost, M.R. (2002). Pattern recognition proteins in Manduca sexta plasma. Insect Biochem. Mol. Biol., 32:1287-1293.

Zhao, P.; Li, J.; Wang, Y. and Jiang, H. (2007). Broad-spectrum antimicrobial activity of the reactive compounds generated in vitro by Manduca sexta phenoloxidase. Ins. Bio. Chem. and Mol. Biol., (9):952959. 
Evaluation of the antimicrobial activity of purified Spodoptera littoralis hemolymph against some pathogenic bacteria

\section{تقييم النشاط المضاد الحيوى للهيموليمف المنقى من حشرة دودة القطن سبودوبتر اليتوراليس ضد بعض البكتيريا الممرضة حثرة}

حنان سيد عامر ${ }^{2}$ دعاء سليمان ${ }^{2}{ }^{2}{ }^{2}{ }^{2}$ 1

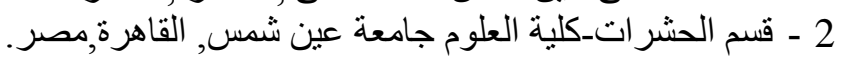

3-قسم البيولوجيا الجزيئية,معهد ابحاث الهندسة الور اثبا والبايوتكنولوجئ فئس , جامعة السادات, المنوفية,مصر.

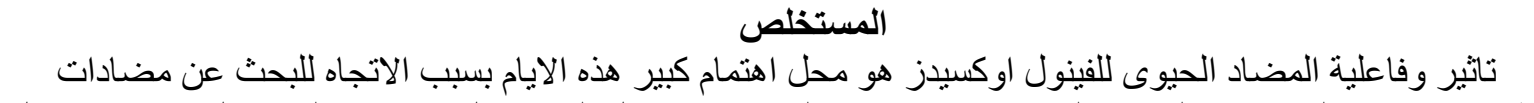

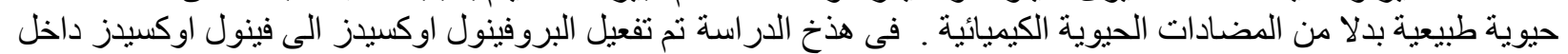
3200

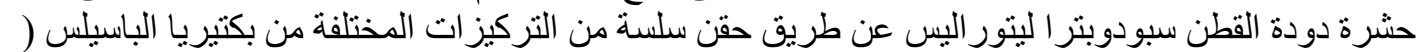

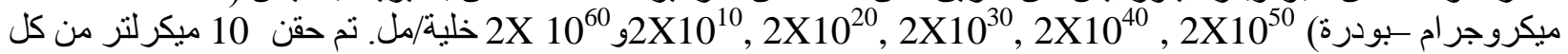

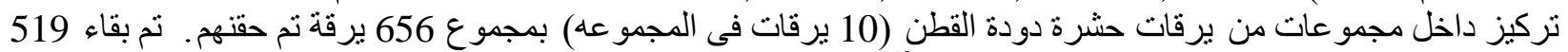

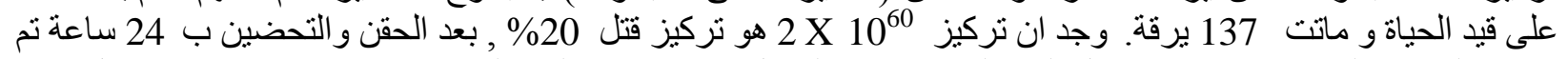

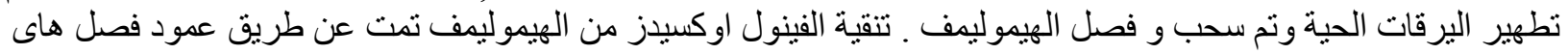

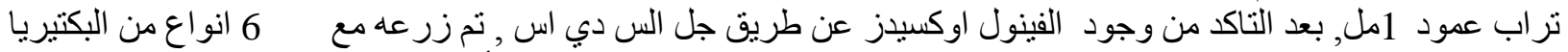

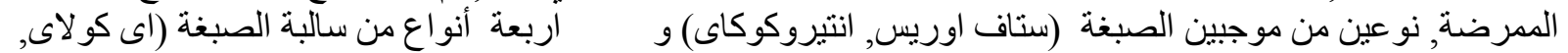

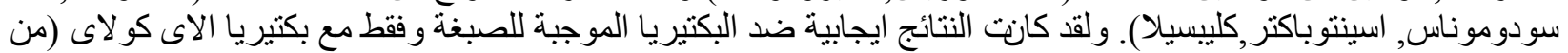

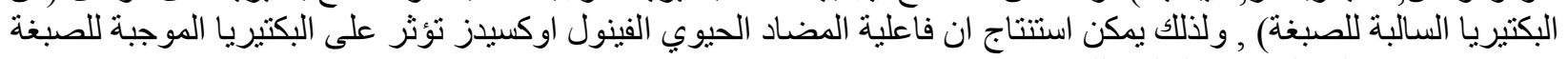

